\section{Bacteria in Experiments on rearing Oyster Larvæ}

THE larvæ of many species of marine invertebrates have proved difficult to rear in the laboratory; the proper control of many factors is required, including food, $p \mathrm{H}$, temperature and stirring. In particular, considerable attention has been given to the requirements of the larvæ of commercial species of lamellibranchs, especially oysters ${ }^{1-4}$. In such work, which has involved long series of rearing experiments, it has been a common experience of workers (in Great Britain and in the United States) that some batches of larvæ fail to develop properly although the conditions provided have been apparently suitable. Some authors have ascribed this result to either the presence or absence of organic substances in the sea water, implying that such substances are either toxic or essential to the proper development of the larvæ. This view has been supported by the work of Wilson ${ }^{5}$ at Plymouth, which has suggested that different natural waters differ in their value as media for developing Echinus larvæ.

Observations which I have made suggest that insufficient attention has been given to the possible development of bacteria in rearing experiments and their effect on the larvæ. The purpose of this communication is to direct attention to the very considerable bacterial population which may quickly develop in such experiments. The effect of the pres. ence or absence of the dissolved organic substances may therefore be indirect in that the bacterial population in a larval rearing experiment is very probably dependent on the concentration of the various dissolved organic substances. The concentration of dissolved organic matter in sea water has received comparatively little attention, but it is known to vary considerably ${ }^{6}$.

During the summer of 1955 , seventeen broods of oyster larvæ were reared under replicate conditions in the laboratory. The experiments were each made in 11 . of sea water at a temperature of $20^{\circ} \mathrm{C}$. Before use, the water was filtered twice through filter candles, the final filtration being through filter candles designed to retain particles more than $1 \mu$ in size. The water therefore contained none of the plankton with the exception of a few bacteria. A few ml. of a concentrated Isochrysis galbana culture and 300-700 larvæ were added to the water. The additions did not appreciably increase the bacterial population.

The density of the bacteria was observed at intervals in each experiment by plating diluted samples in triplicate using ZoBell's agar medium No. $2216^{\text {? }}$. The samples were incubated for $48 \mathrm{hr}$. at $22^{\circ} \mathrm{C}$. and the number of developing colonies estimated by counting ten random microscope fields in each plate. An initial peak, varying between 30,000 and 780,000 bacteria per ml., occurred within three or four days of beginning the experiment. In eight of the seventeen experiments it was more than 200,000 . After the first five days the numbers usually declined to lower levels and remained roughly stationary at 1,000 to 10,000 per $\mathrm{ml}$. If there was a marked mortality of larvæ, a second peak occasionally occurred. These densities were not sufficient to make the water appreciably turbid.

Six of the seventeen experiments can be classed as successful as they yielded more than ten spat. In five of them the initial peak was less than 200,000 per $\mathrm{ml}$. and in the sixth it was 300,000 per $\mathrm{ml}$. Thus, five of the six successful experiments occurred in the nine experiments where the initial peak was less than 200,000. Only one successful experiment occurred in the eight experiments where the peak was more than 200,000 . These experiments suggest, but do not conclusively demonstrate, that, in this case, the bacteria were influencing the successful development of the larvæ. They do, however, clearly show that the bacterial population in such experiments may be considerably in excess of that occurring in the sea, where usually not more than 1,000 per $\mathrm{ml}$. are found ${ }^{7}$. Recent experiments by Oppenheimer ${ }^{8}$ show that dense populations of bacteria may occur in laboratory experiments on hatching marine fish eggs. In this case the percentage hatching was improved when the bacterial population was controlled with antibiotics.

It is clear that, in experiments on rearing marine fish and invertebrate larvæ, the bacterial flora cannot be ignored. Differences which have been observed in the value of different natural waters for rearing larvæ may have their origin in the variation in the size of the bacterial flora which the water can support.

\section{P. R. WALNE}

Ministry of Agriculture, Fisheries and Food,

Fisheries Experiment Station,

Conway.

March 2.

${ }^{2}$ Bruce, J. R., Knight, M., and Parke, M. W., J. Mar. Biol. Assoc. U.K., 24, 337 (1940).

a Davis, H. C., Biol. Bull., 104, 334 (1953).

s Loosanoff, V. L., Amer. Sci., 42, 607 (1954).

4 Walne, P. R., Fish. Invest., ii, 20 (9).

${ }^{5}$ Wilson, D. P., J. Mar. Biol. Assoc. U.K., 30, 1 (1951). - Harvey, H. W., "Biological Chemistry and Physics of Seawater"
(1928).

"ZoBell, C. E., "Marine Microbiology" (1946).

${ }^{8}$ Oppenheimer, C. H., Copeia, 1, 43 (1955).

\section{Effect of Superinfection on Phage Sensi- tivity in Staphylococci}

IT has been known for some time that the sensitivity of bacteria to lysis by bacteriophage is conditioned among other things by the presence of lysogenic infection with one or more bacteriophages. Various workers'-3 have shown that when sensitive cultures were lysogenically infected with typing or even unrelated phages they undergo a change of phage type, the change being a diminution in the number of phages capable of lysing the bacterial cell.

During recent work with staphylococci ${ }^{4}$, it was found that one strain could be lysogenically infected and formed a stable system in which every colony was lysogenic; but the culture was not completely immune to the phage in that high titres of phage gave low counts on the lysogenic culture. It is believed that this is due to the presence of a virulent mutant in the phage. The culture employed was N.C.T.C. 8354 with phage N.C.T.C. 8426 , the lysogenic system formed being $8354 / 8426$.

Further work was carried out using three other staphylococci, 60,98 and 105, and three other phages derived from the staphylococci of similar number, that is, $8354 P$ from $8354,60 P$ from 60 and $105 P$ from 105. These were obtained by filtering the supernatants of overnight broth cultures. The experiments are summarized in Table 1.

It will be seen that when 8354 is rendered lysogenic with $8426 P$ it becomes sensitive to $8354 P, 60 P$ 